\title{
ANALISA EFEKTIVITAS PILOT PROJECT DALAM PERUBAHAN TRANSFORMASIONAL
}

\author{
Kania Mayasari
}

Universitas Airlangga

\begin{abstract}
To improve company performance, Senior Executives took the initiative to make a transformational change as a competitive business strategy. Performance is formed by employee productivity. This change began with a pilot project before it went into national roll-out. Pilots are chosen from the sales force. This study aims to analyze the effectiveness of the pilot project for 5 months to 102 Change Agent Candidates (CAC). Research is descriptive, analyzing quantitative data. The project resulted in significant productivity growth, an increase of $33.7 \%$ with a turnover of $0.9 \%$. Case count productivity penetrated 10.14 from target 9 . Its success cannot be separated from the role of Senior Executives who provide strong engagement. With this success, transformational change can be implemented nationally.
\end{abstract}

$\begin{array}{ll}\text { Keywords } & \text { : effectiveness; pilot project; transformational change } \\ \text { Correspondence to } & \text { : kania.mayasari-2018@feb.unair.ac.id }\end{array}$

\begin{abstract}
ABSTRAK
Untuk memperbaiki performa perusahaan, Eksekutif Senior berinisiatif melakukan perubahan transformasional sebagai strategi bisnis yang kompetitif. Performa terbentuk dari produktivitas karyawan. Perubahan ini diawali dengan pilot project sebelum berlaku nasional. Pilot dipilih dari tenaga pemasaran. Penelitian ini bertujuan untuk menganalisis efektivitas pilot project selama 5 bulan kepada 102 Change Agent Candidate (CAC). Penelitian bersifat deskriptif, menganalisis data kuantitatif. Project menghasilkan pertumbuhan produktivitas yang signifikan, meningkat 33,7\% dengan turn over $0,9 \%$. Produktivitas case count menembus 10,14 dari target 9. Kesuksesannya tidak lepas dari peran Eksekutif Senior yang memberikan engagement yang kuat. Dengan keberhasilan ini, perubahan transformasional dapat diberlakukan secara nasional.
\end{abstract}

Kata kunci : efektivitas; pilot project; perubahan transformasional

Korespondensi $\quad$ : kania.mayasari-2018@feb.unair.ac.id 


\section{PENDAHULUAN}

Sumber daya manusia memegang peranan penting dalam suatu perusahaan. (Mello, 2014) menyatakan bahwa organisasi yang efektif menyadari bahwa setiap karyawan memiliki nilai yang sama besarnya dengan aset fisik dan modal organisasi. Karyawan dengan kinerja yang baik membantu perusahaan mencapai tujuannya. Kinerja karyawan yang terus meningkat berkontribusi positif pada kemajuan perusahaan. Menurut Mangkunegara dalam (Riadi, 2020), kinerja (performa) adalah hasil kerja secara kualitas dan kuantitas seseorang dalam melaksanakan fungsinya sesuai dengan tanggung jawab yang diberikan kepadanya. Faktor-faktor yang mempengaruhi kinerja menurut Sutermeister dalam (Priansa, 2018) adalah motivasi, kemampuan, pengetahuan, keahlian, pendidikan, pengalaman, pelatihan, minat, sikap, kepribadian, kondisi fisik dan kebutuhan fisiologis, kebutuhan sosial serta kebutuhan egoistik. Tantangan bagi manajemen suatu perusahaan adalah bagaimana membuat inisiatif dan menerapkan strategi yang efektif untuk meningkatkan kinerja karyawan. Dengan peningkatan kinerja karyawan memberi efek baik bagi sustainabilitas perusahaan.

PT. X merupakan anak perusahaan dari salah satu bank milik pemerintah yang bergerak di bidang jasa asuransi, menghimpun dana dari nasabah bank tersebut yang tertarik mengikuti program asuransi. Kehadirannya melengkapi eksistensi bank dalam memberikan layanan yang komprehensif bagi semua nasabahnya. PT. X menempatkan tenaga pemasarannya di hampir semua cabang bank tersebut untuk membantu nasabah dalam menjelaskan dan mendaftarkan program asuransi. Kepercayaan nasabah kepada PT. X tergantung dari kemampuan tenaga pemasaran dalam meyakinkan pentingnya asuransi. Dalam hal ini, tenaga pemasaran merupakan garda terdepan yang mewakili perusahaan.

PT. X memiliki sistem penilaian untuk setiap tenaga pemasarannya, yang disebut dengan Key Performance Indicator (KPI), dasar perumusan KPI tersebut mengacu pada produktivitas tenaga pemasaran. KPI menjadi acuan perusahaan dalam melakukan pembayaran kompensasi tenaga pemasaran. Pada penelitian sebelumnya, (Kasenda, 2013) membuktikan bahwa kompensasi dan motivasi kerja memiliki hubungan yang kuat dengan kinerja. Kompensasi yang besar menunjukkan produktivitas yang tinggi. Bagi perusahaan, hal tersebut mengindikasikan potensi tercapainya target perusahaan, profit yang meningkat, level kepuasan nasabah tinggi dan diharapkan berdampak juga pada turn over karyawan yang rendah.

Produktivitas case count tenaga pemasaran PT. X pada tahun ke-7 sejak eksistensinya berada pada angka 7,4. Kemudian pada tahun berikutnya mengalami peningkatan di angka 7,9. Namun pada tahun ke-9 mengalami penurunan produktivitas menjadi 7,7 dan bahkan menurun secara drastis pada tahun ke-10, yaitu di angka 7,1. Berikut tampilannya dalam bentuk grafik di bawah ini.
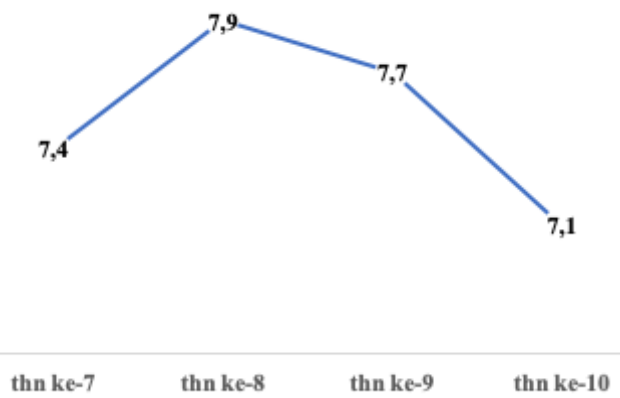

Gambar 1. Produktivitas case count tenaga pemasaran PT. $\mathrm{X}$

Eksekutif Senior mengambil inisiatif untuk melakukan perubahan secara transformasional (transformational change) sebagai bentuk tanggung jawab untuk meningkatkan performa perusahaan dalam lingkungan bisnis yang sangat kompetitif. Di dalam bukunya, (Cummings \& Worley, 2015) menjelaskan bahwa perubahan transformasional biasanya terjadi sebagai respons terhadap atau mengantisipasi perubahan lingkungan, teknologi, atau perubahan internal yang signifikan. 

karakter:

Perubahan transformasional memiliki

1. Perubahan terjadi karena dipicu oleh lingkungan dan gangguan internal.

2. Perubahan ini diprakarsai oleh Eksekutif Senior dan Lini Manajer.

3. Perubahan melibatkan beberapa pemangku kepentingan.

4. Perubahannya bersifat sistemik dan revolusioner.

5. Perubahan itu akan mendapatkan pembelajaran yang signifikan dan menghasilkan paradigma baru.

Perubahan transformasional diawali dengan mengadaptasikan secara internal perusahaan dalam bentuk project dengan menyertakan sejumlah tenaga pemasaran yang akan menjadi pilot. Project memiliki awal dan akhir yang jelas, ruang lingkup, sumber daya, dan anggaran (Turban, et al., 2015). Project harus mendapatkan persetujuan Project Sponsor terlebih dahulu sebelum anggaran dikucurkan dan sumber daya terpilih sudah ditentukan. Menurut uraian (Brown, et al., 2011), ada 4 pendekatan yang bisa dipilih dalam perubahan dari sistem lama ke sistem yang baru, yaitu:

1. Parallel, dimana perusahaan menerapkan sistem lama secara paralel dengan sistem baru sampai sistem baru bekerja dengan efektif.

2. Pilot, yaitu sistem baru diperkenalkan dulu kepada bagian tertentu di perusahaan.

3. Phased, yaitu sistem baru diimplementasikan bertahap setiap komponennya pada suatu waktu.

4. Cutover, yaitu sistem lama langsung ditinggalkan begitu sistem yang baru diimplementasikan.

Pilot project dipilih untuk memastikan kesiapan dari infrastruktur, sarana dan prasarana, serta semua personil yang ada di dalam perusahaan.

Tahapan dalam implementasi project tersebut mengacu pada (Turban, et al., 2015) dengan istilah The Project Management Body of
Knowledge (PMBOK) dimana ada 5 tahapan proses (Gambar 1). Proses diawali dengan ide awal hingga implementasi yang akan mengawal perjalanan project sehingga sukses terlaksana sesuai rencana.

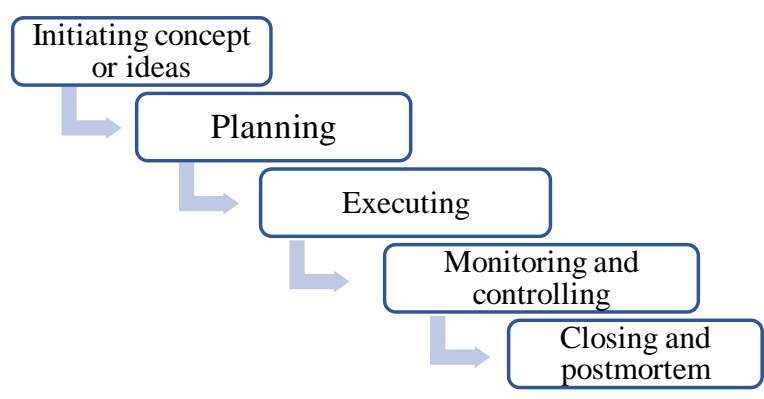

Gambar 2. Tahapan dalam implementasi project.

\section{Initiating concept or ideas}

Pada fase inisiasi awal, dibentuk Flying Team, beranggotakan orang-orang yang memiliki pengetahuan, pengalaman, dan keahlian dalam memasarkan program asuransi, sehingga mampu merumuskan konsep baru berdasarkan kumpulan best practice, kemudian dibukukan menjadi Golden Rules.

Golden Rules disusun sehingga membentuk tahapan yang terstruktur dan memudahkan tenaga pemasaran dalam mengimplementasikannya. Buku ini dilengkapi juga dengan soft skill dan aplikasi penunjang. Secara garis besar, konsep yang terdapat di dalam Golden Rules adalah seperti yang terdapat dalam Gambar 2.

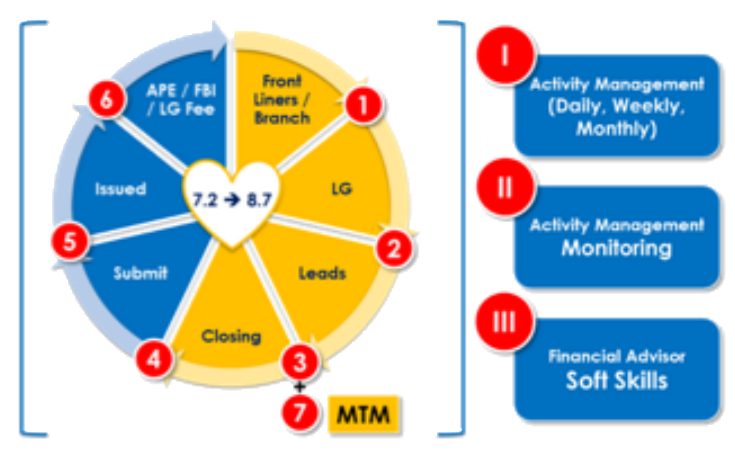

Gambar 3. Konsep Golden Rules

Flying Team bertugas untuk memastikan bahwa Golden Rules diimplementasikan 
secara menyeluruh, mendapatkan tambahan best practice yang bisa menyempurnakan Golden Rules sebelum diberlakukan secara nasional (roll out).

Untuk mendapatkan gambaran secara holistik dalam implementasinya, maka Flying Team melakukan kunjungan lapangan dan melakukan meeting dan joint visit dengan tenaga pemasaran sehingga bisa mendapatkan tambahan wawasan, materi dan feedback untuk ditindaklanjuti.

\section{Planning}

Manajemen membuat struktur pilot project, masing-masing dengan tugas dan tanggung jawabnya. Struktur yang terbentuk:

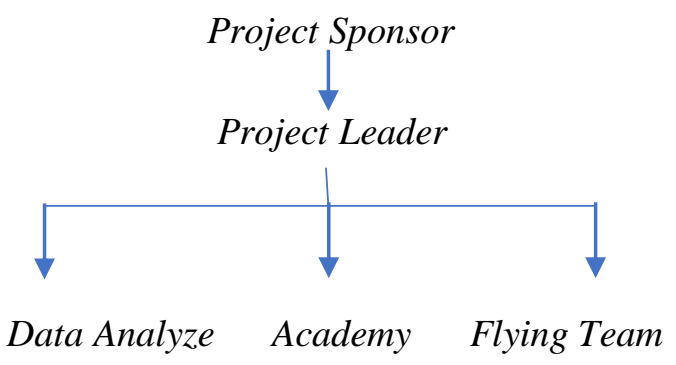

Gambar 4. Struktur Pilot Project

Project Sponsor dipegang oleh Direktur Utama PT. X, selaku Eksekutif Senior yang mengambil inisiatif melakukan perubahan transformasional. Project Sponsor menentukan target yang harus dicapai pilot project dan menetapkan peraturan yang berlaku. Target produktivitas case count untuk pilot project adalah 9 .

Project Leader yang ditunjuk oleh Project Sponsor bertanggung jawab atas tercapainya tujuan dari pilot project dan menganggarkan budget dana yang diperlukan untuk implementasi project.

Pada tahapan ini dilakukan pemilihan tenaga pemasaran yang terpilih menjadi pilot. Setelah project berakhir, mereka yang akan menjadi Change Agent (CA) bagi tenaga pemasaran yang lain. Di dalam blognya, (Couros, 2013) menuliskan karakter yang harus ada pada seorang Change Agent, yaitu:

1. Visi yang jelas

2. Sabar dan gigih

3. Mengajukan pertanyaan sulit (kritis)

4. Berpengetahuan luas dan memimpin dengan memberi contoh

5. Hubungan yang kuat dibangun atas dasar kepercayaan.

Pemilihan Change Agent Candidate (CAC) diambil dari perwakilan setiap region. PT. X memiliki 17 region yang terbagi ke dalam dua grup, yaitu:

Grup 1: Grup yang memasarkan program asuransi konvensional. Grup ini terbagi menjadi 2 wilayah, bagian Barat dan Timur Indonesia. Masing-masing bagian dipimpin oleh seorang Head of Sales. Pada grup ini terdapat 12 region, masingmasing region dipimpin seorang Regional Sales Manager (RSM).

Grup 2: Grup yang memasarkan program asuransi syariah. Grup ini dipimpin oleh seorang Head of Sales. Pada grup ini terdapat 5 region, masingmasing region dipimpin oleh seorang RSM.

Setiap RSM menentukan 6 orang CAC yang terdiri dari:

- 2 orang mewakili produktivitas tinggi.

- 2 orang mewakili produktivitas moderat.

- 2 orang mewakili produktivitas rendah.

Secara keseluruhan didapatkan 102 CAC. Secara piramida, pilot yang terpilih dalam project sebagai berikut:

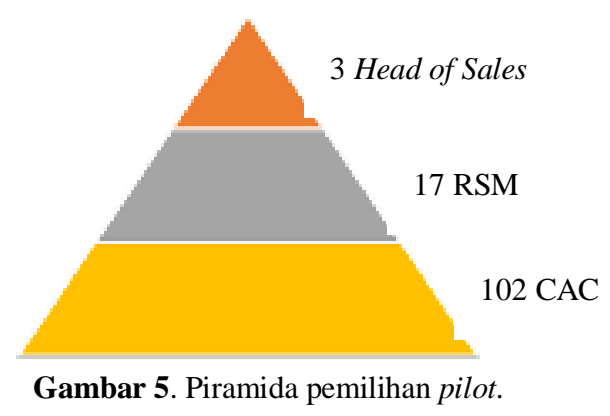


Project didesain dengan pembagian timeline seperti di bawah ini:

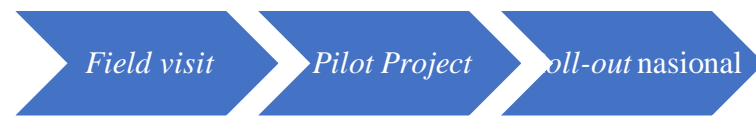

Gambar 6. Timeline project.

Field visit dilakukan satu bulan sebelum project (bulan Juli), dilanjutkan dengan pilot project yang dijalankan selama 5 bulan (Agustus - Desember), sehingga bulan berikutnya (memasuki tahun yang baru) bisa dirilis untuk berlaku secara nasional (rollout).

\section{Executing}

Implementasi project diawali dengan kick-off sebagai tanda dimulainya project, dilakukan di awal Agustus dengan mengundang semua CAC ke Jakarta. Pada bulan sebelumnya, mulai minggu ke-2 bulan Juli, semua CAC sudah mendapatkan sosialisasi awal, dilanjutkan dengan training (pelatihan). Training merupakan bagian yang penting dalam pelaksanaan project ini. Di dalam artikelnya, (Sumaja \& Srinivas, 2020) menyatakan bahwa melalui pelatihan, karyawan memperoleh pengetahuan praktis dan teoritis untuk produktivitas yang lebih tinggi di kinerja pekerjaan.

Selama project, pendampingan pada setiap CAC dijalankan oleh Flying Team dibantu oleh trainer masing-masing region. Pendampingan yang dilakukan berbentuk kunjungan ke setiap CAC dengan melakukan observasi, coaching, meeting, one on one dan joint visit secara terjadwal. Hasil pendampingan digunakan sebagai materi rapat koordinasi pilot project yang dilakukan seminggu sekali.

\section{Monitoring and controlling}

Tahapan ini mencakup analisa data pencapaian yang dilakukan oleh tim data analyze dengan membuat dashboard harian yang disandingkan dengan target pilot, dan mengkaji semua aktivitas CAC dalam proses implementasi Golden Rules.

Flying Team melaporkan hasil pendampingan $\mathrm{CAC}$ dan memastikan project berjalan baik sesuai dengan peraturan yang telah ditetapkan, yaitu:

\section{- Disiplin.}

Setiap CAC disiplin dalam menjalankan semua tahapan dalam Golden Rules, termasuk menggunakan soft skill yang disediakan. Setiap hari mereka mengisi hasil kegiatan harian via aplikasi penunjang yang sudah disediakan. Project member harus menjalankan semua tugas sesuai dengan jadwal yang sudah ditetapkan.

- Transparan.

Setiap CAC menginformasikan semua kendala yang terjadi dalam implementasi Golden Rules. Flying Team memastikan untuk mengeskalasi setiap permasalahan yang ada di lapangan untuk mendapatkan solusi terbaik. Rapat koordinasi merupakan salah satu media untuk menyampaikan semua permasalahan yang terjadi dalam pelaksanaan project. Semua project member memiliki kesempatan yang sama untuk menyampaikan issue yang muncul selama project.

- No gaming.

Setiap CAC harus memiliki integritas yang tinggi, tidak melakukan kecurangan, baik dalam menjalankan proses implementasi maupun pengisian data hasil kegiatan harian. Data analyze melakukan kompilasi data yang diinput CAC, ditampilkan dalam dashboard sebagai bahan analisa, tanpa melakukan rekayasa data. Flying Team mengawasi pelaksanaan di lapangan secara langsung untuk memastikan ketentuan-ketentuan yang telah ditetapkan di atas berjalan baik. Dan Flying Team juga bertugas untuk mendokumentasikan best practice tambahan yang bisa menyempurnakan Golden Rules. 


\section{Closing and postmortem.}

Di akhir project, dari hasil dokumentasi perjalanan project didapatkan lesson learned yang menjadi pembelajaran penting bagi manajemen dalam menentukan langkah berikutnya.

Tujuan dilakukannya penelitian ini adalah untuk menganalisis efektivitas pilot project sebagai upaya perubahan yang dilakukan oleh perusahaan secara transformasional. Pada saat pilot project dijalankan penulis menjadi salah satu anggota Flying Team.

\section{METODE PENELITIAN}

Penelitian yang dilakukan bersifat deskriptif, menganalisis hasil observasi lapangan secara mendalam (etnografi) oleh penulis dari data kuantitatif yang didapatkan dari hasil implementasi pilot project. Data yang dimonitor untuk CAC dalam project ini mencakup:

1. Jumlah nasabah yang ditemui.

2. Jumlah presentasi yang dilakukan.

3. Produktivitas case count.

4. Produktivitas program asuransi tambahan.

Pembahasan untuk penelitian ini dibatasi pada produktivitas case count, yaitu jumlah nasabah yang mengikuti program asuransi untuk masing-masing CAC setiap bulannya selama pilot project.

Beberapa pertimbangan perusahaan menerapkan pilot project di antaranya adalah:

- Menguji Golden Rules, untuk mengidentifikasi best practices yang sesuai dengan kondisi lapangan. Diharapkan dengan metode ini bisa mendapatkan best practices yang paling sesuai sehingga didapatkan Golden Rules yang komprehensif.

- Keterbatasan jumlah anggota Flying Team yang memastikan keberhasilan pelaksanaan project di lapangan.

- Dengan pilot, maka semua project member bisa lebih fokus pada implementasi.

\section{HASIL DAN PEMBAHASAN}

\section{Pre-project}

Pada fase ini, Flying Team melakukan field visit, berinteraksi dengan tenaga pemasaran yang produktif, mendapatkan tambahan wawasan yang bisa digunakan untuk memperkaya metodologi Golden Rules. Selain itu juga melakukan sharing session dengan stakeholder terkait untuk mendapatkan feedback yang diperlukan.

Untuk melihat pertumbuhan produktivitas case count pada saat pilot project, maka harus didapatkan produktivitas case count dari 102 CAC pada fase ini. Dengan mempertimbangkan bahwa project akan dijalankan selama 5 bulan, maka sebagai pembandingnya, dikumpulkan data produktivitas case count 5 bulan sebelum project, dihitung rata-rata produktivitasnya sesuai dengan tabel di bawah ini.

TABEL 1. Produktivitas CAC pra-project

\begin{tabular}{lcccccc}
\hline & Feb & Mar & Apr & Mei & Jun & $\begin{array}{c}\text { Rata- } \\
\text { rata }\end{array}$ \\
\hline Grup 1 & 7.7 & 10.1 & 8.9 & 8.4 & 10.7 & 9.16 \\
\hline Grup 2 & 3.3 & 4.4 & 3.9 & 2.9 & 3.5 & 3.6 \\
\hline Total & 6.6 & 8.3 & 7.5 & 6.8 & 8.7 & 7.58 \\
\hline
\end{tabular}

Grup 1: mewakili CAC yang memasarkan program asuransi konvensional.

Grup 2: mewakili CAC yang memasarkan program asuransi syariah.

Produktivitas di semester 1 periode bulan Februari - Juni, grup 1 unggul dengan produktivitas 9.16 dan grup 2 produktif di angka 3.6. Jika diambil rata-rata dari kedua grup itu, diperoleh produktivitas 7.58.

Fase ini dimanfaatkan juga untuk memastikan bahwa CAC masih aktif sebagai tenaga pemasaran di PT. X dan tidak ada pengajuan pengunduran diri, baik sebagai tenaga pemasaran maupun sebagai CAC.

Satu bulan sebelum project dijalankan, dimulai dari minggu ke-2 bulan Juli, sosialisasi awal dan training bagi semua CAC sudah mulai intensif dijalankan. Pemahaman akan materi 
training diperkuat dengan metode role playing (bermain peran).

Project

Flying Team yang beranggotakan 4 orang, masing-masing berkoordinasi dengan sekitar $26 \mathrm{CAC}$ di dalam 4 region. Setiap minggu menemui CAC secara bergiliran bersama dengan Regional Sales Manager. Flying Team mencatat semua aktivitas, berusaha mendapatkan informasi tambahan dari proses implementasi di lapangan, serta melakukan meeting, coaching, one on one sebagai upaya untuk memantapkan kualitas CAC.

Awal implementasi merupakan masa dengan pendampingan ketat. Walaupun CAC sudah mendapatkan training yang dilengkapi dengan role playing, namun belum bisa mengubah kebiasaan lama, merasa nyaman dengan cara lama.

Masalah yang muncul di awal implementasi secara umum adalah:

1. Awareness. Walaupun pada fase pre-project sudah diberikan sosialisasi, training yang dilengkapi role playing, tidak membuat munculnya kesadaran untuk mengubah mindset, mengubah metodologi pendekatan kepada calon nasabah dan mau menerapkan pengetahuan yang sudah didapatkan selama training. Dalam hal ini diperlukan support motivasi oleh trainer dan RSM agar memiliki kemauan untuk berubah.

2. Underground system, menjalankan cara sendiri dan tidak mematuhi ketentuan yang sudah ditetapkan, seperti melakukan kecurangan data.

3. Tidak sabar. CAC yang sudah menjalankan Golden Rules tidak melakukan sesuai tahapan yang sudah diberikan, dengan argumentasi bahwa prosesnya terlalu lama.

4. Tidak yakin berhasil. CAC masih menganggap bahwa Golden Rules tidak mudah untuk diimplementasikan sehingga diperlukan peran trainer dan RSM untuk melakukan coaching berkesinambungan untuk meningkatkan kepercayaan diri CAC.
Setiap hari Selasa dilakukan meeting koordinasi yang melibatkan Project Sponsor, Regional Sales Manager dan semua project member. Materi bahasannya adalah menganalisis data monitoring, membahas kendala dan hasil field visit.

Peranan Project Sponsor sangat kuat dalam project ini, menegaskan pendapat (Cummings \& Worley, 2015) dalam bukunya, bahwa kepemimpinan Eksekutif Senior dalam skala besar dan perubahan transformasional sangat penting, terutama ketika perubahan harus terjadi dengan cepat. Project Sponsor memenuhi empat karakteristik yang harus dimiliki Eksekutif Senior dalam perubahan transformasional, yaitu:

1. Envisioning.

Eksekutif bisa menggambarkan dengan jelas tujuan dan orientasi strategi baru, diikuti oleh konsistensi yang tinggi dalam memberikan perhatian penuh untuk keberhasilan project. Eksekutif memberikan ruang untuk berdiskusi dan memberikan pencerahan yang membawa pelaksanaan project ke arah yang lebih baik.

2. Energizing.

Eksekutif memiliki antusiasme dan optimisme yang tinggi dan menyebarkan positive feeling dan positive thinking untuk semua yang terlibat dalam project.

3. Enabling.

Eksekutif sangat komunikatif dalam membantu semua stakeholder untuk memahami pentingnya transformasi. Eksekutif memberikan semangat optimisme bahwa project ini bisa berhasil dengan hasil yang membanggakan.

4. Engaging

Eksekutif menetapkan target pencapaian untuk project ini, yaitu produktivitas case count 9, yang terbagi untuk Grup 1 dengan produktivitas case count 12 dan untuk Grup 2 dengan produktivitas case count 6 . Eksekutif memberikan full support untuk tercapainya angka tersebut, seperti membantu mengkomunikasikan dan mengkampanyekan 
pentingnya kesuksesan project ini kepada seluruh stakeholder.

Produktivitas case count hasil implementasi Golden Rules oleh CAC di Grup 1 menunjukkan penurunan di dua bulan pertama implementasi, dengan angka 9,8 (Agustus) dan 10,6 (September). Produktivitas ini di bawah dari produktifitas bulan Juni. Seiring dengan makin meningkatnya awareness dari CAC, pertumbuhan meningkat mulai bulan Oktober, bahkan bulan November dan Desember produktivitas meningkat signifikan, seperti terlihat dari grafik di bawah ini.

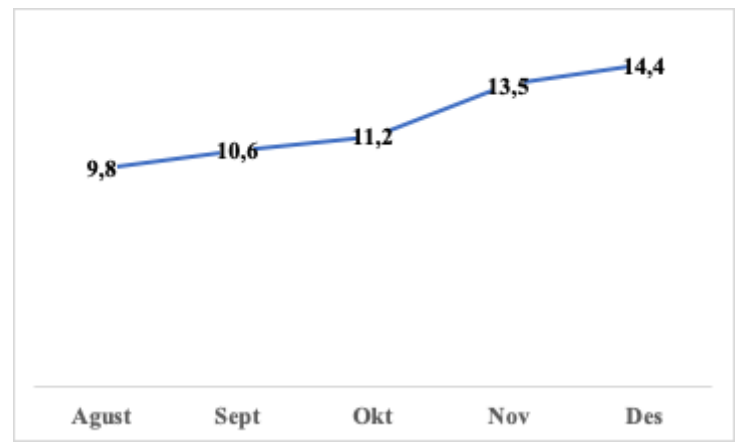

Gambar 7. Produktivitas case count CAC Grup 1

Secara rata-rata, produktivitas case count Grup 1 selama project adalah 11.9 atau tumbuh $30 \%$ dibandingkan sebelum project.

Pertumbuhan produktivitas case count CAC di Grup 2 menunjukkan grafik yang meningkat tajam, secara rata-rata menghasilkan produktivitas case count 5.92 atau tumbuh 64\% dibandingkan sebelum project. CAC di grup ini sudah menunjukkan awareness yang tinggi sejak awal project.

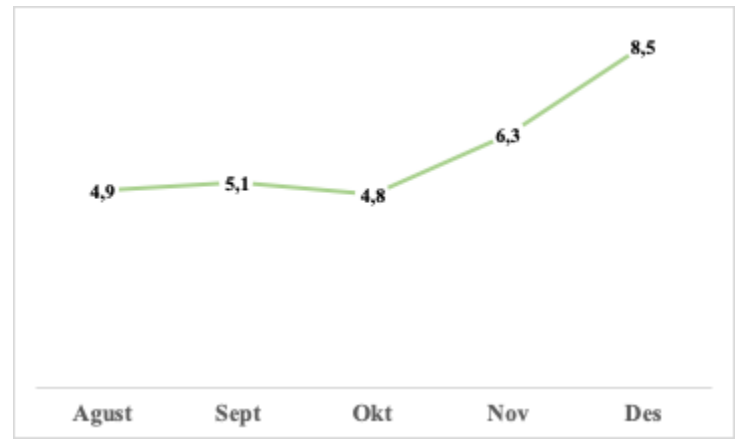

Gambar 8. Produktivitas case count CAC Grup 2.
Secara keseluruhan, produktivitas case count CAC yang berada di Grup 1 maupun di Grup 2 menunjukkan peningkatan, dari produktivitas case count 7.58 menjadi 10.14 atau tumbuh sebesar $33.7 \%$.

Selama project berlangsung, 1 CAC mengundurkan diri, sehingga di akhir project terdapat $101 \mathrm{CAC}$, merekalah yang menjadi Change Agent (CA) pada saat roll- out nasional. Dengan turn over terjaga di $0.9 \%$, hal ini membuktikan bahwa implementasi Golden Rules bisa diterima dengan baik oleh tenaga pemasaran.

\section{KESIMPULAN}

Perubahan transformasional yang diawali dengan pilot project memberikan hasil di atas ekspektasi manajemen, dengan produktivitas case count 10.14 dari target 9. Kesuksesannya tidak lepas dari peran Eksekutif Senior yang memberikan full support, antusiasme, optimisme dan engagement yang kuat pada project ini. Pertumbuhannya menembus $33,7 \%$ dan turn over CAC 0,9\%, maka project perubahan transformasional ini sukses dan bisa dilanjutkan dengan tahap berikutnya, yaitu implementasi secara nasional. CAC berubah peran menjadi Change Agent bagi perusahaan, menjadi role model bagi tenaga pemasaran lainnya.

\section{DAFTAR PUSTAKA}

Brown, C. V et al. (2011) Managing Information Technology: What managers need to know. Pearson Higher Ed.

Couros, G. (2013) The Principal of Change. Available at: https://georgecouros.ca/blog/archives/3615.

Cummings, T. G. and Worley, C. G. (2015) Organization Development \& Change. Stamford: Cengage learning.

Kasenda, R. (2013) 'Kompensasi dan Motivasi, Pengaruhnya terhadap Kinerja Karyawan pada PT. Bangun Wenang Beverages Company Manado', Jurnal Emba: Jurnal Riset Ekonomi, Manajemen, Bisnis dan Akuntansi, 1. doi: https://doi.org/10.35794/emba.v1i3.1894.

Mello, J. A. (2014) Strategic Human Resource Management. 4th edn. Stamford: Cengage Learning.

Priansa, D. J. (2018) Perencanaan \& Pengembangan SDM. Bandung: Alfabeta. 
Riadi, M. (2020) Pengukuran Kinerja (Pengertian, Tujuan, Syarat, Indikator, Model dan Proses), KajianPustaka.com. Available

https://www.kajianpustaka.com/2020/02/pengukuran-

kinerja-pengertian-tujuan-syarat-model-dan-proses.html.

Sumaja, M. and Srinivas, K. (2020) 'The Training Effectiveness on Performance with Special Reference to Vizag Steel Plant', International Journal of Scientific and Technology Research, 9(3), pp. 788-790.

Turban, E., Volonino, L. and Wood, G. R. (2015) Information Technology for Management: Digital Strategies for Insight, Action, and Sustainable Performance. Wiley Publishing. 